\title{
POU Domain, Class 2, Transcription Factor 1
}

National Cancer Institute

\section{Source}

National Cancer Institute. POU Domain, Class 2, Transcription Factor 1. NCI Thesaurus. Code C17521.

POU domain, class 2, transcription factor 1 (743 aa, $76 \mathrm{kDa}$ ) is encoded by the human POU2F1 gene. This protein plays a role in the regulation of transcription. 